Syntax Fusion : Jurnal Nasional Indonesia

e-ISSN : 2775-4440

Vol. 1, No. 9, September 2021

\title{
PENINGKATAN KINERJA GURU DALAM PEMBELAJARAN MELALUI SUPERVISI EDUKATIF, KOLABORATIF SECARA PERIODIK DI SD NEGERI TELUK BETUNG
}

\section{Sionalia}

SD Negeri Teluk Betung

Email: sionalia1968@gmail.com

\begin{abstract}
Abstrak
Motivasi penelitian ini adalah rendahnya kinerja dan wawasan guru di SDN Teluk Betung Kecamatan Kalauguara, hal ini disebabkan oleh beberapa faktor, antara lain rendahnya kesadaran belajar guru dan kurangnya kesempatan guru untuk mengikuti pelatihan, baik secara regional maupun regional. Secara nasional, PKG tidak efisien dan pengawasan pendidikan tidak memadai. Sasaran yang ditujukan untuk meningkatkan proses pembelajaran cenderung menitikberatkan pada aspek administrasi. Berdasarkan permasalahan tersebut, tujuan penelitian yang ingin dicapai adalah meningkatkan kinerja guru dalam pembelajaran di kelas melalui pendidikan reguler dan supervisi kolaboratif. SD Teluk Betung di Kecamatan Kalauguara.

Subyek penelitian ini adalah guru PNS dan GTT dari SD Negeri Teluk Betung. Pengumpulan data penelitian ini meliputi empat kegiatan utama, yaitu pengumpulan data awal, hasil analisis data pada setiap akhir siklus, dan tanggapan guru lain untuk melaksanakan supervisi pendidikan kolaboratif.Analisis data menggunakan analisis kualitatif dan kuantitatif. Hasil penelitian menunjukkan bahwa guru SD Negeri Teluk Betung Kecamatan Kalauguara Kabupaten Barito Selatan mengalami peningkatan kinerja dalam pembelajaran reguler dan supervisi pembelajaran kolaboratif.
\end{abstract}

Kata Kunci: Peningkatan Kinerja, Supervisi, Edukatif, Kolaboratif

\section{Pendahuluan}

Menurut Pasal 1 Ayat 1 "UU Guru" (2006:3), guru adalah pendidik profesional yang tugas pokoknya mendidik, mengajar, dan membimbing peserta didik pada pendidikan anak usia dini melalui pendidikan formal, pendidikan dasar, dan pendidikan menengah. pelatihan, evaluasi dan evaluasi. mendidik. Untuk meningkatkan kualitas pendidikan di Indonesia, pemerintah mengeluarkan Undang-Undang Sistem Pendidikan. Undang-undang tersebut memiliki 22 bab dan 77 pasal dan interpretasinya. UU Sisdiknas (2003:37) menjelaskan bahwa setiap reformasi sistem pendidikan 
nasional adalah untuk memperbaharui visi, misi dan strategi pembangunan pendidikan negara.

Visi pendidikan nasional meliputi (1) mengupayakan perluasan dan pemerataan kesempatan bagi seluruh rakyat Indonesia untuk memperoleh pendidikan yang bermutu, (2) membantu dan memajukan pengembangan potensi negara sejak bayi sampai akhir hayat untuk mewujudkan masyarakat belajar, dan (3 ) meningkatkan derajat persiapan penanaman modal dan mutu proses pendidikan untuk mengoptimalkan pembentukan kepribadian moral, (4) meningkatkan profesionalisme dan rasa tanggung jawab lembaga pendidikan sebagai pusat kebudayaan pengetahuan, keterampilan, pengalaman dan sikap, sebagai serta nilai-nilai berdasarkan standar nasional dan global, (5) Dalam konteks Negara Kesatuan Republik Indonesia, masyarakat diberdayakan untuk berperan serta dalam penyelenggaraan pendidikan sesuai dengan prinsip otonomi.

Jika melihat visi pendidikan, semuanya akan mengarah pada kualitas pendidikan dan pada akhirnya meningkatkan hasil belajar siswa. Kualitas pendidikan dipengaruhi oleh banyak faktor. Menurut Syamsuddin (2005:66), ketiga komponen utama tersebut saling berkaitan dan memiliki kedudukan yang strategis dalam kegiatan pengajaran. Ketiga komponen tersebut adalah kurikulum, guru, dan peserta didik (siswa). Di antara ketiga komponen tersebut, guru menempati posisi sentral karena perannya sangat menentukan.

Dalam pembelajaran, guru harus mampu menerjemahkan nilai-nilai yang terkandung dalam kurikulum dengan sebaik mungkin. Meskipun sistem pembelajaran saat ini tidak lagi menjadi teacher center, namun guru tetap berperan penting dalam membimbing siswa. Kalaupun berbasis guru, harus memiliki pengetahuan yang memadai di bidang akademik dan pengajaran. Menurut Djazuli (1886:2), seorang guru harus memiliki wawasan yang berkaitan dengan mata pelajaran yang diajarkannya dan wawasan yang berkaitan dengan pendidikan agar dapat menyampaikan isi pengajaran kepada siswa. Kedua pandangan ini merupakan satu kesatuan yang tidak dapat dipisahkan.

Guru harus selalu meningkatkan kemampuan, pengetahuan, sikap dan keterampilan profesionalnya sesuai dengan perkembangan ilmu pengetahuan dan teknologi, termasuk paradigma pendidikan baru. Menurut peraturan Direktur Departemen Pendidikan Dasar dan Menengah Depdiknas (2004:2), guru harus memenuhi tiga standar kompetensi, antara lain: (1) kemampuan manajemen pembelajaran dan wawasan pendidikan, (2) akademik/ kemampuan profesional berdasarkan materi pembelajaran, (3) Pengembangan karir. Ketiga kompetensi tersebut bertujuan untuk menumbuhkembangkan guru yang berkualitas dan sekaligus melaksanakan pembelajaran yang berkualitas, dan pada akhirnya meningkatkan kualitas pendidikan di Indonesia.

Untuk mencapai ketiga kemampuan tersebut, sekolah harus melakukan pembinaan kepada guru melalui lokakarya, PKG, diskusi, dan supervisi pendidikan. Hal ini harus dilakukan secara rutin guna meningkatkan kinerja dan wawasan guru, karena menurut diskusi yang dilakukan oleh guru di SD Negeri Teluk Betung Kabupaten Karau 
Kuala rendahnya kinerja dan wawasan guru disebabkan oleh (1) sikap guru yang rendah. kesadaran belajar yang rendah, (2) guru Kurangnya kesempatan untuk mengikuti pelatihan di tingkat daerah dan nasional, (3) PKG kurang efisien, dan (4) supervisi pendidikan yang ditujukan untuk meningkatkan proses pembelajaran cenderung terfokus pada aspek administrasi. Untuk memperbaiki kinerja dan wawasan guru dalam pembelajaran di SD Negeri 1 Teluk Betung kecanatan Karau Kuala, sekolah melaksanakan penelitian tindakan yang berkaitan dengan permasalahan di atas.

\section{Metode Penelitian}

Penelitian ini dilaksanakan di SDN Teluk Betung Kecamatan Kalauguara pada tahun pelajaran 2018/2019. Pada tahun itu, banyak hasil penelitian yang tidak mengarah pada peningkatan kualitas pendidikan. Peneliti melakukan penelitian di SD Negeri Teluk Betung Kabupaten Karau Kuala, karena SD merupakan SD binaan penelitian. Guru GTT dan PNS di SDN Teluk Betung Kecamatan Kalauguara.

Masa studi adalah tahun ajaran 2019/2020. Selama proses penelitian, peneliti mengumpulkan data awal, merumuskan rencana pengawasan, dan melakukan pengawasan, analisis dan pelacakan. Teknik pengumpulan data pada penelitian ini terdiri atas empat kegiatan pokok yakni pengumpulan data awal, data hasil analisis setiap akhir siklus, serta tanggapan lain dari guru terhadap pelaksanaan supervisi edukatif model kolaboratif.

Data yang telah dikumpulkan dianalisis dengan menggunakan analisis kualitatif dan kuantitatif. Analisis kualitatif digunakan untuk menjelaskan perubahan perilaku guru dalam pembelajaran dan perilaku Peneliti dalam melaksanakan supervisi guru. Adapun analisis kuantitatif digunakan untuk mengetahui keberhasilan guru dan siswa berdasarkan standar kompetensi guru yang telah ditetapkan oleh Depdiknas sebagai berikut.
a. Nilai $81-100=$ amatbaik (A) berhasil
b. Nilai $76-80=$ baik $(B)$ berhasil
c. $\quad$ Nilai $55-75=\operatorname{cukup}(\mathrm{C})$ belum berhasil
d. Nilai $0-54=$ kurang (D) belum berhasil

Indeks keberhasilan yang dicapai peneliti dalam penelitian ini adalah apakah rata-rata persentase keberhasilan guru kelas mengalami peningkatan. Tolok ukur nilai keberhasilan guru adalah $>75$. Kinerja guru yang dimaksudkan sebagai indikator keberhasilan meliputi: kinerja guru dalam menyusun RPP, kinerja guru dalam melaksanakan pembelajaran, kinerja guru dalam mengevaluasi kinerja siswa, dan kinerja guru dalam menelusuri hasil evaluasi kinerja siswa. Dengan meningkatnya kinerja guru dapat menghasilkan pembelajaran yang efektif dan dapat memotivasi siswa untuk belajar dengan meningkatkan hasil belajar, terutama nilai ujian semester. 


\section{Hasil dan Pembahasan}

\section{A. Hasil dan Temuan Siklus I}

Berdasarkan pemantauan selama persiapan, pelaksanaan, dan tindak lanjut penelitian tindakan ini diperoleh berbagai data baik dari guru yang sedang melaksanakan proses belajar mengajar, siswa yang belajar, Peneliti yang sedang melaksanakan supervisisnya. Gambaran yang merupakan hasil dan temuan penelitian sebagai berikut.

\section{Hasil Pelaksanaan Siklus I}

Hasil siklus pertama dapat dilihat pada tabel berikut ini

$\underline{\text { Tabel } 1}$

Hasil Penentuan Perencanaan Siklus I

\begin{tabular}{|c|c|c|c|c|}
\hline No. & Indikator & $\begin{array}{l}\text { Jumlah } \\
\text { Guru }\end{array}$ & $\begin{array}{c}\text { JML Guru } \\
\text { Berhasil(Skor } \geq \\
75\end{array}$ & $\begin{array}{l}\% \text { Keber- } \\
\text { hasilan }\end{array}$ \\
\hline 1 & $\begin{array}{l}\text { Mendeskripsikan Tujuan } \\
\text { Pembelajaran }\end{array}$ & 6 & 5 & 83 \\
\hline 2 & $\begin{array}{l}\text { Menentukan materi sesuai dengan } \\
\text { kompetensi }\end{array}$ & 6 & 5 & 83 \\
\hline 3 & $\begin{array}{l}\text { Mengorganisasikan materi } \\
\text { berdasarkan urutan atau kelompok }\end{array}$ & 6 & 4 & 66,4 \\
\hline 4 & Mengalokasikan waktu & 6 & 6 & 100 \\
\hline 5 & Menentukan metode pembelajaran & 6 & 3 & 49,8 \\
\hline 6 & Merancang prosedur pembelajaran & 6 & 4 & 66,4 \\
\hline 7 & Menentukan media pembelajaran & 6 & 4 & 66,4 \\
\hline 8 & $\begin{array}{l}\text { Menentukan sumber belajar yang } \\
\text { sesuai (berupa buku, modul, } \\
\text { program komputer dan sejenisnya) }\end{array}$ & 6 & 5 & 83 \\
\hline 9 & $\begin{array}{l}\text { Menentukan teknik penilaian yang } \\
\text { sesuai }\end{array}$ & 6 & 3 & 49,8 \\
\hline & Rata - Rata Keberhasilan & & & $71,98 \%$ \\
\hline
\end{tabular}

Tabel 2

Hasil Melaksanakan Pembelajaran Tindakan Siklus I

\begin{tabular}{|c|c|c|c|c|}
\hline No & Indikator & $\begin{array}{l}\text { Jumlah } \\
\text { Guru }\end{array}$ & $\begin{array}{c}\text { JML Guru } \\
\text { Berhasil } \\
\text { (Skor } \geq 75\end{array}$ & $\begin{array}{c}\% \\
\text { Keberhas } \\
\text { ilan }\end{array}$ \\
\hline 1 & $\begin{array}{l}\text { Membuka pelajaran dengan metode yang } \\
\text { tepat }\end{array}$ & 6 & 5 & 83 \\
\hline 2 & $\begin{array}{l}\text { Menyajikan materi pelajaran secara } \\
\text { sistematis }\end{array}$ & 6 & 4 & 66,4 \\
\hline 3 & Menerapkan metode dan & 6 & 4 & 66,4 \\
\hline
\end{tabular}




\begin{tabular}{llllc}
\hline \multicolumn{2}{l}{ pembelajaran yang telah ditentukan } & & & \\
\hline 4 & Mengatur kegiatan siswa di kelas & 6 & 5 & 83 \\
\hline 5 & Menentukan media pembelajaran & 6 & 4 & 66,4 \\
\hline 6 & Menggunakan sumber belajar & 6 & 4 & 66,4 \\
\hline 7 & $\begin{array}{l}\text { Memotivasi siswa dengan berbagai cara } \\
\text { yang positif }\end{array}$ & 6 & 5 & 83 \\
\hline 8 & $\begin{array}{l}\text { Melakukan interaksi dengan siswa } \\
\text { menggunakan bahasa yang komunikatif }\end{array}$ & 6 & 5 & 83 \\
\hline 9 & Memberikan pertanyaan dan umpan balik & 6 & 4 & 66,4 \\
\hline 10 & Menyimpulkan pembelajaran & 6 & 4 & 66,4 \\
\hline 11 & Menggunakan waktu secara efektif & 6 & 4 & 66,4 \\
\hline & Rata - Rata Keberhasilan & & & $72,44 \%$ \\
\hline
\end{tabular}

$\underline{\text { Tabel } 3}$

Hasil Menilai Prestasi Belajar Siklus I

\begin{tabular}{llccc}
\hline No. & \multicolumn{1}{c}{ Indikator } & $\begin{array}{c}\text { Jumlah } \\
\text { Guru }\end{array}$ & $\begin{array}{c}\text { JML Guru } \\
\text { Berhasil(Skor } \geq \\
75\end{array}$ & $\begin{array}{c}\text { \% Keber- } \\
\text { hasilan }\end{array}$ \\
\hline 1 & Menyusun soal/perangkat penilaian & 6 & 5 & 83 \\
\hline 2 & Melaksanakan penilaian & 6 & 5 & 83 \\
\hline 3 & Memeriksa jawaban/memberi skor & 6 & 4 & 66,4 \\
\hline 4 & Menilai hasil belajar & 6 & 6 & 100 \\
\hline 5 & Mengolah hasil belajar & 6 & 4 & 66,4 \\
\hline 6 & Menganalisis hasil belajar & 6 & 4 & 66,4 \\
\hline 7 & Menyimpulkan hasil belajar & 6 & 4 & 66,4 \\
\hline 8 & Menyusun laporan hasil belajar & 6 & 6 & 100 \\
\hline 9 & Memperbaiki soal/perangkat & 6 & 6 & 100 \\
\hline & penilaian & & & $81,3 \%$ \\
\hline
\end{tabular}

Tabel 4

Hasil Melaksnakan Tindak Lanjut Hasil Penilaian Siklus I

\begin{tabular}{clccc}
\hline No. & \multicolumn{1}{c}{ Indikator } & $\begin{array}{c}\text { Jumlah } \\
\text { Guru }\end{array}$ & $\begin{array}{c}\text { JML Guru } \\
\text { Berhasil } \\
\text { (Skor } \geq 75\end{array}$ & $\begin{array}{c}\% \\
\text { Keber- } \\
\text { hasilan }\end{array}$ \\
\hline 1 & $\begin{array}{l}\text { Mengidentifikasi kebutuhan tindak } \\
\text { lanjut hasil penilaian }\end{array}$ & 6 & 4 & 66,4 \\
\hline 2 & Menyusun program tindak lanjut & 6 & 5 & 83 \\
\hline 3 & Melaksanakan tindak lanjut & 6 & 3 & 49,8 \\
\hline 4 & Mengevaluasi hasil tindak lanjut & 6 & 3 & 49,8 \\
\hline
\end{tabular}




\begin{tabular}{|c|c|c|c|}
\hline & hasil penilaian & & \\
\hline \multirow[t]{2}{*}{5} & $\begin{array}{l}\text { Menganalisis hasil evaluasi } \\
\text { program tindak lanjut hasil } \\
\text { penilaian }\end{array}$ & 6 & 49,8 \\
\hline & Rata-rata Keberhasilan & & $59,76 \%$ \\
\hline
\end{tabular}

\section{Pelaksanaan Tindak Lanjut Siklus I}

Berdasarkan deskripsi dan refleksi di atas, peneliti, guru dan Peneliti melakukan tindak lanjut yang berkaitan dengan tindakan-tindakan yang perlu dilakukan pada siklus kedua, baik yang berkaitan dengan perencanaan, pelaksanaan, maupun penilaian.

\section{a. Tindak Lanjut Perencanaan Supervisi Siklus I}

Guru yang disupervisi dibantu oleh Peneliti membuat perencanaan pembelajaran yang kriterianya berdasarkan pada indikator yang telah dibuat oleh Dirjen Dikmenum dengan memperhatikan:

(1) Memperjelas tujuan pembelajaran yang ada dalam GBPP/ Kurikulum yang berlaku dengan membuat tujuan khusus pembelajaran

(2) Materi pembelajaran dibuat sesederhana mungkin dan urut dari yang sederhana ke yang sulit. Materi itu ditulis di RPP guru.

(3) Menentukan pembagian alokasi waktu secara spisifik dan berdasarkan pada langkah-langkah pembelajaran dan metodenya.

(4) Menentukan media pembelajaran secara kontekstual dan berdasarkan pada materi yang dipelajari siswa.

(5) Teknik penilaian didasarkan pada keterampilan atau materi yang diberikan.

\section{b. Tindak Lanjut Pelaksanaan Supervisi Siklus I}

Pada siklus I pelaksanaan supervisi difokuskan pada kerja sama dalam pembelajaran di kelas. Guru senior atau guru yang sudah mampu membantu pada guru yunior atau guru yang belum mampu dalam pelaksanaan pembelajaran. Contoh-contoh pembelajaran perlu diperhatikan oleh guru yang belum mampu tersebut, terutama melakukan hal-hal berikut.

(1)Guru senior atau yang sudah mampu melaksanakan pembelajaran memberi contoh pada guru yunior (guru yang belum mampu) dalam membuka pelajaran dengan cara apersepsi dan menggali skemata siswa yang berkaitan dengan materi sebelumnya.

(2)Guru melaksanakan pembelajaran sesuai dengan perencanaan yang dibuat bersama dengan memperhatikan langkah-langkah yang ada dalam RPP.

(3)Penggunaan media difokuskan pada benda-benda yang ada di lingkungan sekolah. Tentu saja disesuaikan dengan materi yang dipelajari siswa.

(4)Guru membagi papan tulis menjadi tiga bagian, yakni bagian pertama digunakan untuk menulis tujuan yang ingin dicapai. Bagian kedua untuk tanya jawab atau tulisan yang berkaitan dengan proses pembelajaran. Bagian ketiga digunakan untuk kesimpulan.

\section{c. Tindak Lanjut Penilaian Pembelajaran Siklus I}


Pada bagian penilaian ini guru berdiskusi dengan guru lain untuk menentukan penilaian yang cocok untuk pokok bahasan atau KD yang akan disampaikan pada siswa. Hal yang perlu dilaksanakan sebagai perbaikan siklus I adalah:

(1) Pembuatan kisi-kisi ulangan dititikberatkan pada ulangan uraian objektif dan satu uraian non objektif.

(2) Pelaksanaan penilaian dikelompokkan menjadi dua, yakni dalam proses, yang soalnya berupa pertanyaan yang dijawab secara langsung oleh siswa, kedua soal-soal yang dibuat untuk dikerjakan setelah proses pembelajaran.

(3) Guru selalu mendiskusikan dengan teman guru atau dengan Peneliti untuk menentukan skor, bobot, analisis butir soal, dan perbaikan soal, menyimpulkan hasil dan melaporkan hasil penilaian.

\section{d. Pelaksanaan Tindak Lanjut Penilaian Siklus I}

Pada bagian penilaian ini guru berdiskusi dengan guru lain untuk menentukan tindak lanjut penilaian karena banyak bagian yang belum dipahami oleh guru-guru SD Negeri Teluk Betung Kecamatan Karau KualaUntuk itu, ada beberapa rekomendasi yang perlu ditindaklanjuti pada siklus II yaitu: Para guru SD Negeri Teluk Betung Kecamatan Karau Kuala perlu work shop tentang tindak lanjut penilaian, untuk membicarakan: (a) identifikasi tindak lanjut hasil penilaian, (b) menyusun program tindak lanjut, (c) Melaksanakan tindak lanjut, (d) mengevaluasi hasil tindak lanjut, (e) menganalisis hasil evaluasi program tindak lanjut hasil penilaian.

\section{B. Hasil dan Temuan Siklus II}

Siklus II dilaksanakan berdasarkan temuan siklus I. Bagian yang sudah baik dipertahankan, sedangkan bagian yang persentasi keberhasilannya kecil diperbaiki pada siklus II ini. Berdasarkan refleksi dan pelaksanaan tindak lanjut siklus I, maka gambaran hasil dan temuan yang perlu ditindaklanjuti sebagai berikut.

\section{Hasil Pelaksanaan Siklus II}

Hasil siklus pertama dapat dilihat pada tabel berikut ini

$\underline{\text { Tabel } 5}$

Hasil Penentuan Perencanaan Siklus II

\begin{tabular}{llccc}
\hline No. & \multicolumn{1}{c}{ Indikator } & $\begin{array}{c}\text { Jumlah } \\
\text { Guru }\end{array}$ & $\begin{array}{c}\text { JML Guru } \\
\text { Berhasil } \\
\text { Skor } \geq 75\end{array}$ & $\begin{array}{c}\% \text { Keber- } \\
\text { hasilan }\end{array}$ \\
\hline 1 & Mendeskripsikan Tujuan Pembelajaran & 6 & 6 & 100 \\
\hline 2 & $\begin{array}{l}\text { Menentukan materi sesuai dengan } \\
\text { kompetensi }\end{array}$ & 6 & 6 & 100 \\
\hline 3 & $\begin{array}{l}\text { Mengorganisasikan materi berdasarkan } \\
\text { urutan atau kelompok }\end{array}$ & 6 & 5 & 83 \\
\hline 4 & Mengalokasikan waktu & 6 & 6 & 100 \\
\hline 5 & Menentukan metode pembelajaran & 6 & 5 & 83 \\
\hline 6 & Merancang prosedur pembelajaran & 6 & 5 & 83 \\
\hline 7 & Menentukan media pembelajaran & 6 & 5 & 83 \\
\hline 8 & Menentukan sumber belajar yang sesuai & & 6 & 100 \\
\hline
\end{tabular}




\begin{tabular}{llccc}
\hline & $\begin{array}{l}\text { (berupa buku, modul, program komputer } \\
\text { dan sejenisnya) }\end{array}$ & 6 & & \\
\hline 9 & Menentukan teknik penilaian yang sesuai & 6 & 6 & 100 \\
\hline & Rata - Rata Keberhasilan & & & $92,44 \%$ \\
\hline
\end{tabular}

$\underline{\text { Tabel } 6}$

Hasil Melaksanakan Pembelajaran Tindakan Siklus II

\begin{tabular}{lllll}
\hline No. & \multicolumn{1}{c}{ Indikator } & $\begin{array}{c}\text { Jumlah } \\
\text { Guru }\end{array}$ & $\begin{array}{c}\text { JML Guru } \\
\text { Berhasil } \\
\text { (Skor } \geq 75)\end{array}$ & $\begin{array}{c}\text { \% Keber- } \\
\text { hasilan }\end{array}$ \\
\hline 1 & $\begin{array}{l}\text { Membuka pelajaran dengan metode yang } \\
\text { tepat }\end{array}$ & 6 & 6 & 100 \\
\hline 2 & $\begin{array}{l}\text { Menyajikan materi pelajaran secara } \\
\text { sistematis }\end{array}$ & 6 & 5 & 83 \\
\hline 3 & $\begin{array}{l}\text { Menerapkan metode dan prosedur } \\
\text { pembelajaran yang telah ditentukan }\end{array}$ & 6 & 5 & 83 \\
\hline 4 & Mengatur kegiatan siswa di kelas & 6 & 6 & 100 \\
\hline 5 & Menentukan media pembelajaran & 6 & 5 & 83 \\
\hline 6 & Menggunakan sumber belajar & 6 & 6 & 100 \\
\hline 7 & $\begin{array}{l}\text { Memotivasi siswa dengan berbagai cara } \\
\text { yang positif }\end{array}$ & 6 & 6 & 100 \\
\hline 8 & $\begin{array}{l}\text { Melakukan interaksi dengan siswa } \\
\text { menggunakan bahasa yang komunikatif }\end{array}$ & 6 & 6 & 100 \\
\hline 9 & Memberikan pertanyaan dan umpan balik & 6 & 5 & 83 \\
\hline 10 & Menyimpulkan pembelajaran & 6 & 6 & 100 \\
\hline 11 & Menggunakan waktu secara efektif & 6 & 6 & 100 \\
\hline & Rata - Rata Keberhasilan & & $93,81 \%$ \\
\hline
\end{tabular}

Tabel 7

Hasil Menilai Prestasi Belajar Siklus II

\begin{tabular}{llccc}
\hline No. & \multicolumn{1}{c}{ Indikator } & $\begin{array}{c}\text { Jumlah } \\
\text { Guru }\end{array}$ & $\begin{array}{c}\text { JML Guru } \\
\text { Berhasil } \\
(\text { Skor } \geq 75)\end{array}$ & $\begin{array}{c}\% \\
\text { Keber- } \\
\text { hasilan }\end{array}$ \\
\hline 1 & Menyusun soal/perangkat penilaian & 6 & 5 & 83 \\
\hline 2 & Melaksanakan penilaian & 6 & 5 & 83 \\
\hline 3 & Memeriksa jawaban/memberi skor & 6 & 5 & 83 \\
\hline 4 & Menilai hasil belajar & 6 & 6 & 100 \\
\hline 5 & Mengolah hasil belajar & 6 & 6 & 100 \\
\hline
\end{tabular}




\begin{tabular}{clccc}
\hline 6 & Menganalisis hasil belajar & 6 & 5 & 83 \\
\hline 7 & Menyimpulkan hasil belajar & 6 & 5 & 83 \\
\hline 8 & Menyusun laporan hasil belajar & 6 & 6 & 100 \\
\hline 9 & $\begin{array}{l}\text { Memperbaiki soal/perangkat } \\
\text { penilaian }\end{array}$ & 6 & 6 & 100 \\
\hline$\quad$ Rata - Rata Keberhasilan & & & $90.56 \%$ \\
\hline
\end{tabular}

$\underline{\text { Tabel } 8}$

Hasil Melaksnakan Tindak Lanjut Hasil Penilaian Siklus II

\begin{tabular}{clccc}
\hline No. & \multicolumn{1}{c}{ Indikator } & $\begin{array}{c}\text { Jumlah } \\
\text { Guru }\end{array}$ & $\begin{array}{c}\text { JML Guru } \\
\text { Berhasil } \\
\text { (Skor } \geq 75)\end{array}$ & $\begin{array}{c}\% \\
\text { Keber- } \\
\text { hasilan }\end{array}$ \\
\hline 1 & $\begin{array}{l}\text { Mengidentifikasi kebutuhan tindak } \\
\text { lanjut hasil penilaian }\end{array}$ & 6 & 5 & 83 \\
\hline 2 & Menyusun program tindak lanjut & 6 & 5 & 83 \\
\hline 3 & Melaksanakan tindak lanjut & 6 & 5 & 83 \\
\hline 4 & $\begin{array}{l}\text { Mengevaluasi hasil tindak lanjut } \\
\text { hasil penilaian }\end{array}$ & 6 & 5 & 83 \\
\hline 5 & $\begin{array}{l}\text { Menganalisis hasil evaluasi program } \\
\text { tindak lanjut hasil penilaian }\end{array}$ & 6 & 5 & 83 \\
\hline & Rata-rata Keberhasilan & & & $83 \%$ \\
\hline
\end{tabular}

\section{Hasil Tindakan Penelitian Siklus II}

Berdasarkan deskripsi dan refleksi di atas, peneliti, guru dan Peneliti menghentikan penelitian tindakan ini karena hasil yang diperoleh setelah tindakan, baik yang dilakukan oleh peneliti maupun guru sudah memuaskan. Tindakan-tindakan guru yang dapat meningkatkan hasil supervisi guru sebagai berikut.

\section{a. Perencanaan Supervisi}

Tindakan guru dan Peneliti pada perencanaan supervisi edukatif kolaboratif yang dapat meningkatkan kinerja guru adalah:

1) Guru dan Peneliti selalu bekerja sama dalam membuat persiapan supervisi. Bekerja sama tersebut termasuk menentukan instrumen penilaian, pelaksanaan, dan penilaian hasil siswa.

2) Setelah instrumen supervisi selesai, guru diberi format penilaian seminggu sebelum pelaksanaan supervisi dan Peneliti selalu menanyakan kekurangmampuan dan kekurang jelasan format penilaian tersebut.

3) Peneliti menanyakan perangkat pembelajaran seminggu sebelum pelaksanaan baik yang berkaitan dengan pembelajaran maupun penilaian.

\section{b. Pelaksanaan Supervisi}


1) Guru dan Peneliti selalu bekerja sama melaksanakan pembelajaran. Peneliti membuka pelajaran dengan apersepsi dan menggunakan skemata siswa, kemudian dilanjutkan oleh guru yang disupervisi.

2) Dalam pelaksanaan supervisi, guru merasa nyaman pada saat mengajarnya karena Peneliti dalam mensupervisi seperti rekanan guru yang mengajar bersama di kelas.

3) Peneliti mengamati guru yang sedang mengajar dengan catatan-catatan khusus tentang kejadian positif dan negatif pada pembelajaran tersebut.

4) Guru memberi penilaian proses dengan berdasarkan persiapan yang dikerjakan dengan peneliti.

5) Peneliti dan guru mendiskusikan kelebihan dan kekurangan pembelajaran. Bagain yang kurang langsung dicarikan solosinya.

\section{c. Penilaian Supervisi}

1) Guru melaksanakan penilaian berdasarkan program yang sudah dibuat.

2) Penilaian difokuskan pada bentuk uraian objektif dan uraian non-objektif.

3) Penyusunan soal dilaksanakan secara koaboratif dengan peneliti.

4) Pengoreksian hasil evaluasi dilakukan secara langsung oleh guru setelah pembelajaran. Hal seperti itu dilakukan dengan peneliti.

5) Guru menyimpulkan hasil belajar siswa dan melaporkan hasilnya kepada kepala sekolah.

\section{d. Hasil Tindakan Peneliti}

Hasil refleksi pada bagian pelaksanaan supervisi dan setelah diadakan diskusi dengan guru sebagai berikut.

(1) Peneliti memeberikan indikator yang harus dicapai pada saat persiapan, pelaksanaan, dan penilaian seminggu sebelum pelaksanaan supervisi,

(2) Peneliti menyuruh guru mengisi format penilaian yang ingin dicapai, satu minggu sebelum pelaksanaan supervisi,

(3) Peneliti mendiskusikan persiapan dengan guru yang akan disupervisi,

(4) Peneliti mengamati guru pada saat supervisi,

(5) Peneliti berdiskusi dengan guru setelah melaksanakan supervisi,

(6) Guru dan Peneliti membuat perencanaan kembali kegiatan berikutnya yang akan disupervisi

\section{Pembahasan Hasil Penelitian}

Pembahasan didasarkan pada teori-teori yang sudah ada, baik berdasarkan pada referensi mapun dari ucapan ahli di bidang penelitian ini.

Adapun pembahasan hasil penelitian ini sebagai berikut.

Temuan pertama, kinerja guru dalam membuat RPP meningkat. Hal ini dikarenakan guru kelas saling bekerjasama dan dibimbing oleh peneliti. Temuan kedua, kinerja guru dalam pembelajaran mengalami peningkatan. Dalam penelitian tindakan ini, hampir semua dari 6 guru mampu belajar dengan baik. Hal ini terlihat dari hasil pengawasan. Temuan ketiga, kinerja guru dalam menilai kinerja siswa mengalami 
peningkatan. Penelitian tindakan yang dilakukan di SD Negeri Teluk Betung Kabupaten Karau Kualaini menunjukkan bahwa pelaksanaan supervisi pendidikan kolaboratif secara berkala bagi guru menyiapkan soal/alat penilaian, melaksanakan, memeriksa, mengevaluasi, mengolah, menganalisis, merangkum, menulis laporan dan memecahkan masalah. Sebelum melakukan supervisi pendidikan kolaboratif, banyak guru yang mengalami kesulitan dalam melakukan evaluasi. Temuan keempat, guru mengalami peningkatan dalam tindak lanjut hasil evaluasi prestasi akademik siswa.

Temuan kelima, kinerja guru dalam menyusun rencana pembelajaran, melaksanakan pembelajaran, mengevaluasi kinerja pembelajaran, dan menelusuri hasil kinerja siswa mengalami peningkatan.

\section{Kesimpulan}

Berdasarkan temuan hasil penelitian ada empat hal yang dikemukakan dalam penelitian tindakan ini, yakni simpulan tentang: (1) Peningkatan kinerja guru dalam menyusun rencana pembelajaran, (2) Peningkatan kinerja guru dalam melaksanakan pembelajaran, (3) Peningkatan kinerja guru dalam menilai prestasi belajar, (4) Peningkatan kinerja guru dalam melaksanakan tindak lanjut hasil penilaian prestasi belajar siswa. 
Sionalia

\section{Biliografi}

Anwar, Moch. Idochi. 2004. Administrasi Pendidikan dan Manajemen Biaya Pendidikan. Bandung: Alfabeta

Depdiknas. 1997. Petunjuk Pengelolaan Adminstrasi Sekolah Dasar. Jakarta: Depdiknas.

Depdiknas. 2001. Manajemen Peningkatan Mutu Berbasis Sekolah. Jakarta: Depdiknas.

Depdiknas. 2010. Supervisi Akademik; Materi Pelatihan Penguatan Kemampuan Kepala Sekolah; Jakarta: Depdiknas.

Harahap, Baharuddin. 1983. Supervisi Pendidikan yang Dilaksanakan oleh Guru, Kepala Sekolah, Penilik dan Pengawas Sekolah. Jakarta: Damai Jaya

Majid, Abdul. 2005. Perencanaan Pembelajaran: Mengembangkan Standar Kompetensi Guru. Bandung: PT Remaja Rosdakarya.

Muhaimin (2004). Paradigma Pendidikan Islam. Bandung: PT Remaja Rosdakarya.

Mulyasa, E., 2003. Kurikulum Berbasis Kompetensi: Konsep, Karakteristik, dan Implementasi. Bandung: PT Remaja Rosdakarya

Sahertian, Piet A. 2000. Konsep-Konsep dan Teknik Supervisi Pendidikan Dalam Rangka Pengembangan Sumber Daya Manusia. Jakarta: Rineka Cipta.

Sapari, Achmad. 2002. Pemahaman Guru Terhadap Inovasi Pendidikan. Artikel. Jakarta: Kompas (16 Agustus 2002).

Supandi. 1996. Administrasi dan Supervisi Pendidikan. Jakarta: Departemen Agama Universitas Terbuka.

Suprihatin, MD. 1989. Administrasi Pendidikan, Fungsi dan Tanggung Jawab Kepala Sekolah sebagai Administrator dan Supervisor Sekolah. Semarang: IKIP Semarang Press.

Surya, Muhammad. 2003. Psikologi Pembelajaran dan Pengajaran. Bandung: Yayasan Bhakti Winaya

Suryasubrata.1997. Proses Belajar Mengajar di Sekolah. Jakarta: Rineka Cipta. 